\title{
Heads from the North: Transcultural Memorialization of the 1965 Indonesian Killings at the National Gallery of Australia
}

\author{
Katharine McGregor
}

Memories of the 1965 violence continue to reverberate across the generations in Indonesia. Children impacted by the violence have chosen to express or not express their experiences in different ways depending on the audiences they address. This chapter considers the functions and messages of a memorial to the victims of the violence created by Dadang Christanto, an Indonesian whose father was murdered in 1965. The memorial takes the form of a bronze sculpture series in the sculpture garden of the National Gallery of Australia (NGA).

This chapter has been completed with the support of the Australian Research Council Future Fellowship (FT130100957) for the project Confronting Historical Injustice in Indonesia: Memory and Transnational Human Rights Activism.

K. McGregor $(\square)$

School of Historical and Philosophical Studies,

The University of Melbourne, Melbourne, VIC, Australia

(C) The Author(s) 2018

K. McGregor et al. (eds.), The Indonesian Genocide of 1965,

Palgrave Studies in the History of Genocide,

https://doi.org/10.1007/978-3-319-71455-4_12 
Heads from the North can be considered a transcultural memorial in the sense it largely memorializes violence that took place in "another" country at the hands of members of "another" nation. This memorial is part of a larger trend of transcultural memorialization. Yet as the only permanent memorial to all victims of the 1965 violence in the world, including Indonesia, it is unique. Reflecting on Australia's implication in the 1965 violence and Christanto's relationship to Australia, this chapter asks what kinds of memory work this permanent memorial fulfills?

Throughout the chapter, I use the term transcultural memory following Astrid Erll to refer to the shift in memory studies away from the idea of nation states as containers of memory, to instead capture mnemonic processes unfolding across and beyond cultures (Erll, 2011, p. 9). I consider whether transnational memorials work to bring relatively forgotten violent pasts into memory or to further erase them, and how they bring the histories of different countries and peoples into dialogue. This chapter also highlights the fact that through the movement of people and ideas, memories of 1965 have travelled across space such that they are increasingly becoming part of global memory of mass violence.

\section{Transcultural Memorials}

Transcultural memorials to violence that occurred in other places are perhaps most prevalent in the United States. Sometimes such memorials have been created with direct government support and at other times they are more a product of community-based efforts. The US Congress, for example, endorsed the now famous United States Holocaust Memorial Museum, which opened in 1993 as a "living memorial" to the Holocaust. It was directed towards "remembering the victims, honoring the survivors, and ensuring their history remains both a cautionary tale and a vital lesson to future generations" (Bloomfield, 2006, p. xv). This lesson was to be extended to people, nations and institutions that stood by as the Holocaust unfolded.

Located in Washington on the National Mall, this is a national memorial. The creation of this museum is in part related to the presence of a large Jewish diaspora consisting of Holocaust survivors and their families in the United States, but it is also related to the increasing universalization of messages of the Holocaust as the most horrific crime of the twentieth century. At the time of its opening, the genocide in 
Bosnia was unfolding. Over time this museum has expanded to include other comparative cases such as the Cambodian, Bosnian and Rwandan genocides.

American diaspora and activist communities have also initiated memorials to cases of violence that occurred outside of America. The comfort women memorials-in Palisades Park, New Jersey; Long Island, New York; Glendale, California; and Fairfax, Virginia-are, for example, projects initiated by Korean-American communities who either feel aggrieved by what they perceive as continuing Japanese denials about the war-time comfort women system or seek to link this issue to modernday sex-trafficking (McCarthy, 2014). They seek to use their location in America, a superpower with close ties to Japan, to pressure the Japanese government to do more on the case. ${ }^{1}$ Further to this, Cambodian Americans have created various memorials and small museums to remember the victims of the Cambodian genocide of 1975-1979. In this process, America's anti-Communist history has created a supportive context for the elevation of this history of what are often perceived to be "Communist crimes". Yet Cambodian Americans have also sought through their remembrance to remind American audiences of US complicity in the rise of the Khmer Rouge and continued support for the Khmer Rouge after the Vietnamese takeover in 1979 (Schlund-Vias, 2012).

Perhaps due to its relatively minor status in world politics, with the exception of a few Holocaust memorials, there are far fewer transcultural memorials in Australia to non-Australian victims of violence abroad. Christanto's sculpture was one of the first such memorials. Before considering the memorial and its creator in more detail, I would like to reflect on Australia's relationship with the 1965 violence as context for understanding this memorial.

\section{Australia And the 1965 Violence}

At the time the attack on the PKI (Partai Komunis Indonesia, Indonesian Communist Party) and leftist sympathizers began in late 1965, relations between Indonesia and Australia were tense. There were fears about the spread of Communism from Vietnam and potentially Indonesia southwards to Australia. The first Australian troops entered the Vietnam War in 1962 to fight against what the Australian 
government represented as a Communist regime. There were also fears about President Sukarno and his increasing embrace of the PKI, and his firm stand against the British and Americans. From February 1965, Australia contributed a small number of troops to fight with British Commonwealth troops in an undeclared war against the Indonesian army in the so-called Malaysia Confrontation (Mackie, 1974).

The Australian government accepted the Army's interpretation of the 30 September Movement as a Communist plot and encouraged Australian media outlets to replicate the Indonesian Army's position on the Movement and on the repression of the PKI (Najjarine \& Cottle, 2003). Australian Prime Minister Harold Holt was generally guarded in what he said about the violence, but during a less formal meeting with the Australian-American Association at the River Club in New York, he said: "With 500,000 to I million Communist sympathizers knocked off, I think it is safe to assume a reorientation has taken place" (cited in Tanter, 2002). As Robert Cribb noted, there was a noticeable lack of moral outrage internationally at the killings (1990, p. 6). The Australian government was largely supportive of the new military regime emerging under General Suharto, and it certainly did not condemn the large scale massacre in Indonesia.

As detailed above, Cambodians who suffered under the Khmer Rouge regime and who were refugees from this period have been the driving force for the creation of US memorials to the Cambodian genocide. There is an Indonesian diaspora in Australia, but unlike the Cambodian diaspora in the United States, this is not a community primarily made up of persons who fled persecution in their home country. I do not know of a systematic study of how many people were able to flee Indonesia in 1965. Some Indonesians on the political left were trapped abroad, unable to return for fear of persecution. Very few who remained in Indonesia, however, were able to escape because of the rapid pace of the repression, the fact they did not anticipate the scale of the repression, a lack of resources, curfews, airport controls and the unwillingness of many countries to grant asylum to persons considered to be Communists. Indonesian embassies engaged in a screening process of Indonesians abroad, requiring those with suspect backgrounds to choose to return home or lose their passports (Barton, 2002, pp. 90-97). Not only was there hostility to Communists in Australia, the White Australia policy was 
still in place until 1966 and the government only made exceptions for Colombo Plan students and professionals whose skills were in demand.

The few exiles from the Indonesian Left that made it to Australia generally kept their histories relatively hidden with some exceptions. Meanwhile, Australian prime ministers continued throughout the Suharto regime to praise Suharto, ignoring the regime's record of violence (Hyland, 2008). Although some journalists, activists and a few scholars continued to highlight the 1965 violence and its legacies, it would be fair to say there was a reluctance to talk about the violence critically in broader circles in Australia. David Hill has suggested this is connected to Australian scholarly concern about continuing access to Indonesia, but it may also be connected to the lack of a motivated and vocal leftist Indonesian diaspora to back this process (Hill, 2009). The Australian government became further entangled in support for the military-dominated Suharto regime through its official recognition of the 1975 Indonesian takeover of East Timor.

After the fall of the Suharto regime in 1998, and following trends in Indonesia of greater press openness, there was more media discussion of Indonesia in the Australian press. One could say that Australian media attention to the role of the Indonesian military also escalated during the May 1998 riots and in the post-independence ballot violence in East Timor in 1999 (Tapsell \& Eidenfalk, 2013, pp. 587-590). There was a new spotlight on the military's human rights record.

In the context of expectations of ongoing reform and democratization, and a new opening around discussions of the 1965 violence in Indonesia, the NGA sponsored a sculpture by Australian Indonesian artist Dadang Christanto entitled Heads from the North. This was a significant sculpture, firstly because it took up the theme of the 1965 Indonesian violence; secondly because it was intended as a memorial to those who died; and thirdly because it was unveiled on 1 October 2004. I October is a highly charged day in the Indonesian commemorative calendar-Sacred Pancasila (Hari Kesaktiaan Pancasila), which in effect celebrates the crushing of the Communists ("Drowning", 2004). After the fall of the Suharto regime, there were expectations that antiCommunism would soften in Indonesia but, as detailed in Chapter 15 by Miller, this has not proven to be the case. 


\section{The National Gallery and the Commissioning OF HEADS FROM THE NORTH}

Christanto's sculpture series consists of 66 bronze heads cast from six different clay moulds located in a marsh pond. The heads and a small section of the neck attached to each head protrude out of the water to look at a viewer from a number of angles through the reeds (Fig. 12.1). The pond is surrounded by indigenous plants and is shaded by trees producing a secluded feel. There is an extra aura around the pond when the nearby fog generated by Fujiko Nakaja's Fog sculpture emits steam at intervals throughout the day. At those times the faces eerily peep through the mist.

The number 66 symbolizes the last year of the most intense violence. Christanto notes he chose the number 66 over 65 because sometimes people associate 1965 with the 30 September Movement only and not the violence that came after it, and for the practical reason that he wanted to reproduce six moulds evenly across the 66 sculptured heads (personal communication, June 29, 2015).

So how did this work come to be part of the permanent exhibition of the NGA, and what does this mean in terms of its significance? In commissioning the work, the NGA curator, Melanie Eastburn, explained the Gallery was following a long tradition of a commitment to collecting

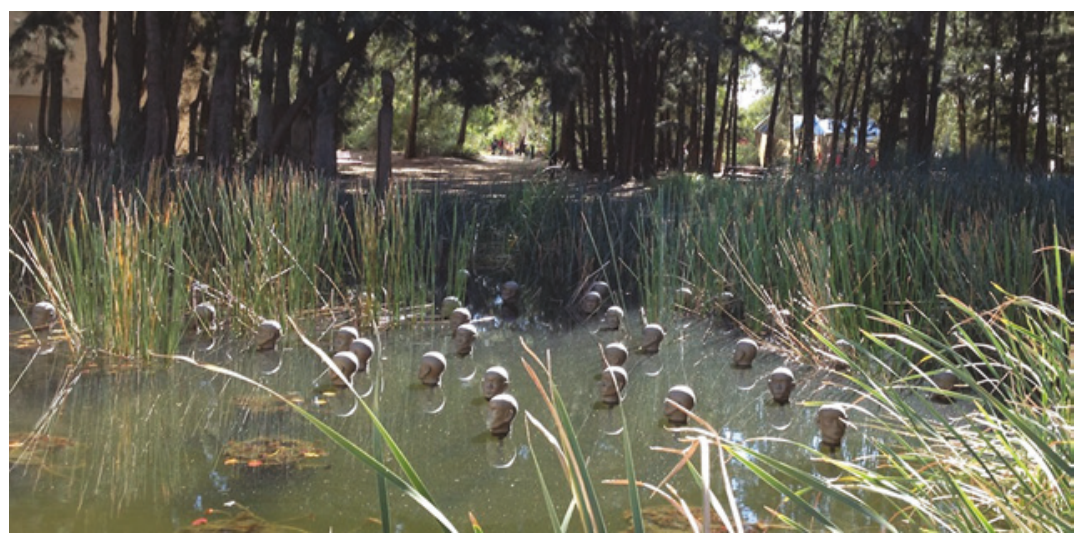

Fig. 12.1 Heads from the North, National Gallery of Australia Sculpture Garden, photograph by author 
art from Southeast Asia (personal communication, May 7, 2015). The NGA is a relatively new institution. In fact, in March 1966 as the violence in Indonesia was still underway, a Committee of Inquiry was working to formulate the basis of the Gallery. The Inquiry reported to Prime Minister Harold Holt that aesthetic merit should be the foundation of the acquisition policy, but that there should also be a commitment to "art representing the high cultural achievement of Australia's neighbors... before its disappearance", as well as "art of the twentieth century on a worldwide basis" (National Art Gallery, 1966, p. 1). The 1960s assumption about the disappearance of particular art forms in the region reflects a widespread colonial view about a golden age of Indonesian art, dating in particular to the Hindu Buddhist past of Indonesia (McGregor, 2004, pp. 15-30). By the early 2000s, the Gallery had increasingly begun to collect contemporary Asian art, but there were very few pieces by modern Indonesian artists.

It is notable then that Heads from the North was the second of Christanto's works acquired by the Gallery. The first was a piece also relating to the 1965 violence called Red Rain. Red Rain consists of a collection of drawings on small pieces of gold paper, faces of people encased in plastic, symbolizing identity cards (Turner, 2007b, p. 93). From each face hung in a canopy, a long thin red thread falls to the ground. The thread references tears of blood shed for victims of human rights abuses. A private art foundation, The Sherman Contemporary Art Foundation, funded Red Rain. The Chairman and Executive Director Gene Sherman describes the aim of the Foundation as to "bring audiences into conversation with history via a focus on artists who mesh complex world and national stories with contemporary realities" (Sherman, 2009, p. 63). Sherman's commitment to political art stems from her life experiences. Born to an Austro-German family in South Africa, she left the country in 1964 with her parents in protest at the continuation of apartheid $(\mathrm{Ng}, 2014$, p. 53). She has consistently supported critical art practice, such as the work of Dinh Q Le, whose 2011 installation entitled Erasure featured "thousands of black and white photos of families and individuals, some who might have died or gone missing during the American-Vietnam War" (Ng, 2014, p. 53). ${ }^{2}$ The Foundation supports socially engaged artists who take up issues related to violence and loss and who thus create "connected aesthetics" (Sherman, 2009, p. 64). 
It was through Dadang Christanto's reputation for aesthetically superior art and the Gallery's ownership of the Red Rain installation that he was chosen to create the first new piece for the sculpture garden in many years. Curator Melanie Eastburn stresses that this choice was very much about the artist, rather than the politics of his work or any kind of social justice initiative (personal communication, May 7, 2015). Yet all of Christanto's work includes references to social and political issues. Art scholar Caroline Turner notes Christanto is amongst a small group of activist-artists born from the 1950s onwards, such as F. X. Harsono, Arahmaini, Heri Dono and Moelyono to take up issues of human rights in Indonesia including economic marginalization (Turner, 2007b, pp. 86-87).

Christanto was free to choose the theme of his NGA sculpture. His first idea was to install 200 terracotta heads in Lake Burley Griffin, but one concern was they would have washed away. Moreover, the lake did not form part of the national estate space allocated to the gallery and the adjacent High Court (personal communication, June 29, 2015). Following from themes in his earlier works, he was interested in an installation around water so he chose to base the work around the marsh pond within the existing sculpture garden. In 1996 Dadang famously placed 1001 full body sized fiberglass figures of naked men and women into the sea at Ancol beach in north Jakarta where they disappeared into the surf (Maxwell, 2004). This art project called 1001 Earth People was inspired by the 1992 Kedung Ombo Dam project in which poor villagers were displaced for unfair compensation to make way for a dam.

In an interview, Christanto commented that water is a vital element in the Mababarata story and other folk legends in Java, and that it thus has a "sacred and holy" meaning (Eastburn, 2008). He wanted to use water in both the 1001 Earth People installation and in Heads from the North "as a metaphor for suffering and torture" (Eastburn, 2008). In 1001 Earth People, only part of the fiberglass bodies was submerged in the water when he released them into the sea. In Heads from the North by contrast he positioned the head and neck of the bronze sculptures at the waterline to signal the more intense danger the people killed in 1965 faced (personal communication, June 29, 2015). Water is also an important theme in the mass violence of 1965 , due to the disposal of corpses and decapitated heads in rivers and seas. As Hearman (2013) has noted in her work on oral histories about this period in East Java, a frequent recurring image is that of the Brantas River and bodies floating in it. 
She describes this oral imagery as a convenient way of "trying to convey the horrors to audiences". For these reasons, water summons memories of the 1965 killings.

Heads are also a recurrent image in Christanto's work. Turner explains this choice by noting "the head is the site of memory and of intelligent thought" and "it is only through memory and intelligent thought, through recollection and reflection that trauma caused by violence can be cured and reconciliation achieved" (Turner, 2007a, p. 18). Christanto thus used heads in both Red Rain and Heads from the North to signal memories as well as violent deaths (Fig. 12.2).

\section{Personal Memory and Heads from the North}

One reason the sculpture is so haunting, for informed visitors at least, is that this piece touches on a very personal history for the artist. Christanto grew up in a family of ethnic Chinese background in a village called Kamantran in Tegal, Central Java. His father, Tak Ek Tjiu, owned a small business. He sympathized with the PKI, but according to Christanto's mother, he was not a PKI member. The military took his father away early one morning when the family was sleeping (Kronenberg \& Herbert, 2006). This was in October 1965, so very early in the repression. This timing seems to coincide with the arrival of army crack troops RPKAD (Resimen Para Komando Angkatan Darat, Army Para Commandos Regiment) into Central Java, who carried out the killings and armed and trained local anti-Communist groups to kill (Jenkins

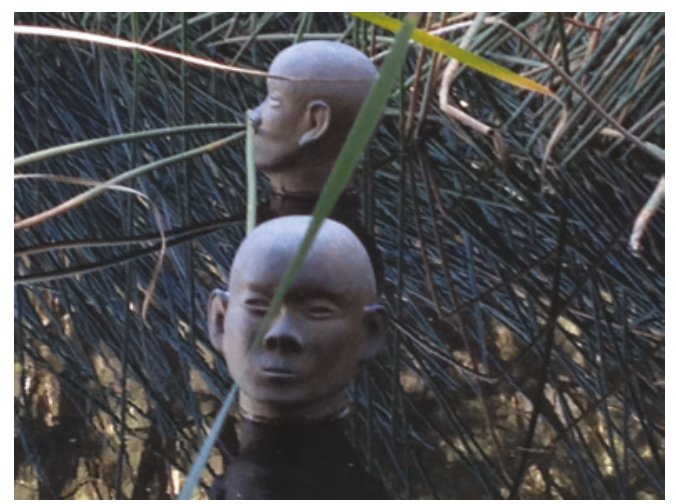

Fig. 12.2 Individual head in Heads from the North, National Gallery of Australia Sculpture Garden, photograph by author 
\& Kammen, 2012, pp. 83-90). Christanto was a child only eight years old at the time. He never saw his father again.

His father's disappearance, however, was not his first experience of the persecution of his family. Three years earlier, his family's house was burned down in anti-Chinese attacks led by outsiders. Reflecting on his sense of isolation, he stated in an interview that "Even though I was five I felt we were different" (personal communication, June 29, 2015). The ethnic Chinese were not the primary targets of the 1965 violence in Indonesia, but some were certainly targeted. ${ }^{3}$ Due to the events of 1965 , Dadang, however, became a person who was subjected to double discrimination. His village was located in a Nadhlatul Ulama (NU) stronghold where most residents were santri, devout Muslims, and he was often teased on the basis, for example, of being Chinese and not circumcised as well as being the child of a PKI (personal communication, June $29,2015)$. The taunting was so bad in his local area that he was sent to live with an aunt in Bandung. As discussed in Chapters 11, 13, and 14 by Setiawan, Lis and Dragojlovic, many children of persons accused of being Communists, whether imprisoned or killed, suffered discrimination because of the pervasive anti-Communist propaganda continually propagated by the regime and replicated in society. Christanto had similar experiences (personal communication, June 29, 2015). He remembers he did not want to go to school because people teased him for being the son of a PKI person (Kronenberg \& Herbert, 2006).

Christanto attended art school during 1975-1977 at the Indonesian Academy of Fine Arts in Yogyakarta. He did not reveal his personal background, however, until migrating to Australia in 1999. His story fits with the patterns of intergenerational memory of many children of people targeted in the violence who often choose to conceal their parents' pasts.

The installation Red Rain, which Christanto created after migrating to Australia, was the first time he directly referenced the 1965 violence in his work. He notes "when I made Red Rain [2003] was the first I was clearly talking about my father, straightly and clearly" (Kronenberg \& Herbert, 2006). In this installation, as noted above, he used red string to symbolize "bloodshed everywhere". He also used joss paper "because it is a symbol of praying for the Chinese tradition" (Kronenberg \& Herbert, 2006). He combined references to both his Chinese identity and his personal loss in relation to 1965 in this piece.

Christanto felt freer living in Australia to represent this history. He was able to make a break from the common practice of using 
metaphorical references to controversial events that was necessary in the authoritarian context of the Suharto regime. He felt released from the paranoia he experienced living under the Suharto regime (personal communication, June 29, 2015). Turner comments that living away from his homeland has had the effect of "liberating his expression of his full identity as an Indonesian of Chinese ethnicity and identity" (Turner, 2007b, pp. 92-93).

His new capacity to talk about 1965 was also, however, related to changes in Indonesia and more open discussion by former political prisoners of their experiences and increased advocacy for them. At the time he made Red Rain, for example, President Wahid had three years earlier made the very hopeful personal apology to victims of 1965 for the role of NU in the violence and had suggested the revocation of TAP MPRS XXV 1966 (Purwardi, 2003, pp. 49-67). Yet there were also signs of firm resistance to opening this past, including the forced disruption of the attempted reburial of remains from a forest grave from 1965 in the town of Kaloran, north of Yogyakarta in 2001. I have argued elsewhere that this reburial was symbolically important for many families who had lost loved ones in 1965 and who had no knowledge of the whereabouts of their family members' remains (McGregor, 2012, p. 250). This was true also for Christanto, who was moved by an SBS documentary directed by Mike Carey covering the story of one man to find his brother's remains, which led to the Wonosobo excavation. ${ }^{4}$ The documentary led him to ask why discrimination against those considered PKI had endured so long in Indonesia (Ingham, 2003, p. 22).

Many of the killings took place in secret in secluded forests after executioners picked up groups of prisoners from their homes or from jail at night (Hearman, 2013, pp. 105, 108). In the same year he completed Heads from the North, Christanto finished another installation called Witness (2004) in which he affixed metal to sections of branches in a tree in a work commissioned by the Australian National University. Speaking about that work he said:

the trees became witness when there is [sic] slaughter in the forest. I am curious to ask where is my father? The body? But nobody answer about that, nobody and I ask to the trees. And when I ask to the trees the trees just crying, crying, crying... If they can talk if they can explain, they will explain about the brutality of regime (Kronenberg \& Herbert, 2006). 
In this statement, Christanto reveals the extent to which he continues to be troubled by the lack of information about the final resting place of his father. His position mirrors that of thousands of other Indonesian families who lost loved ones who have been unable to search for or locate their relatives ("1965 survivor", 2015). Christanto is committed to repeatedly representing his responses to the violence, despite the sorrow it has caused him. He feels that he has to "be a witness" to that past, to prevent it from recurring (Kronenberg \& Herbert, 2006).

\section{Heads from the North as a Transcultural Memorial}

I now want to turn to the question of in what sense Heads from the North functions as a memorial, and the transcultural dimensions of this work. Heads from the North is both a personal memorial for Christanto and also a transcultural memorial to those who died. It is extremely personal for the artist because each of the six faces used as moulds for the 66 heads were modeled on different expressions of his parents' faces. When the installation was opened on 1 October 2004 Christanto symbolically smeared ceremonial ash on his face and body and moved between the sculptured heads in the pond touching them gently ("Drowning", 2004). This sculpture is therefore a form of memorial to his parents for the loss of his father and the suffering of both his mother and the broader family. But it is also a memorial to all the victims of 1965 (personal communication, June 29, 2015).

This work is remarkable because despite several plans, there is not yet to my knowledge a purposefully built monument to all the victims of 1965 in Indonesia. There are markers to sites where people died such as wells, caves and bridges throughout Java and Bali, but there are almost no permanent memorials to those who died. One exception is the small tombstone in a forest in Wonosari district near Semarang, naming the victims buried in a mass grave, which was installed in June 2015. A Semarang-based human rights group gained permission for the tombstone after eight months of prior socialization of this idea (Narudin, $2015)$. One reason for the extreme hostility to the reburial of remains of 65 victims in Kaloran in 2001 was the fear that the new gravesites might become a memorial for all those who died in 1965 (McGregor, 2012, pp. 249-250). Similar fears were expressed regarding the Semarang tombstone, with a condition for the memorial being that all activities at the site had to be coordinated with the owners of the land, the Ministry of Forestry. There is a sense then that it is not yet possible to memorialize all the victims of 1965 collectively in Indonesia. 
So how does this transcultural memorialization of the 1965 violence work? Originally there was no plaque attached to this piece in the sculpture garden. Perhaps this led to some confusion from those who looked upon the installation. Only later was a plaque with the following text added (Fig. 12.3).

Curiously the text does not acknowledge who perpetrated the violence, nor does it acknowledge the international support, including Australian support, for the violence. It does, however, acknowledge the brutality of the repression and the mass nature of the killings, although no figure for the number of people killed is provided.

What is interesting about this transcultural memorial is that Heads from the North is not defined exclusively by Christanto's country of origin. Instead the installation reflects his complex positionality and what literary critics Syed Manzurul Islam has described as a "migrant's memory event" (1999, p. 119). This term refers to the performance of memories by a migrant that reflects making sense of multiple belongings across time and space. Although this concept was developed in the field of literary studies by Islam to apply in particular to the works of Salman Rushdie, Anne Ring Peterson has extended this term to apply to the work of Palestinian exile and artist Mona Hatoum's work (Peterson, 2013). This term is equally useful for thinking about Christanto's work.

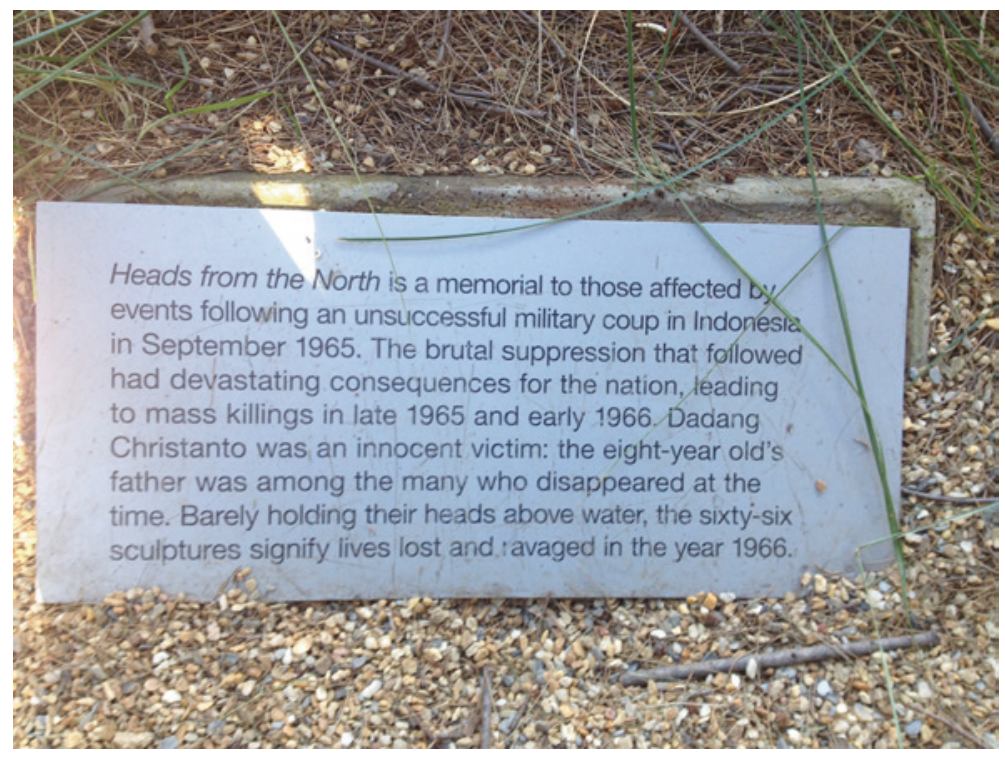

Fig. 12.3 Plaque for Heads from the North, National Gallery of Australia Sculpture Garden, photograph by author 
Firstly, the title of the work, Heads from the North, signals that Christanto is looking at this past from the location of Australia. He explained in an interview that he used water as a total concept for this piece to signal not only suffering and torture, and perhaps the specifics of the 1965 violence, but also the water between Australia and Indonesia as Australians look "North" (personal communication, June 29, 2015). Here he wanted to reference the domination of the Australian imagination of Indonesia as a place where there are many stories of violence, tragedy and people smuggling. He sought thus to tap into a long history of the white Australian cartographical imagination of the North, including fears of invasion by both so-called Asians and Communists (Broinowski, 1992). Christanto thus invites visitors to the gallery to look north, but also to examine a particular history of the "North". In doing so, I read this as a call to both remember and to think about the relationship between Australia and Indonesia, including the relationship at the time the violence took place.

Although 1965 was the specific inspiration for the work, Christanto notes he was also inspired by the desire to memorialize the many victims of both conflict and natural disaster in the twentieth century, which he describes as "a horrible century" (Kronenberg \& Herbert, 2006). Like the case of the Holocaust Museum in the United States, Christanto seeks to connect the history of the 1965 violence in Indonesia with other histories of violence and more universal suffering. Christanto also acknowledges it is difficult for younger audiences to understand the Cold War and the geopolitics of the 1960s, especially for Indonesians given New Order versions of history, so he chooses to represent the 1965 violence in a more abstract, universal way as a human tragedy (personal communication, June 29, 2015). But I wonder if there is a risk of the specifics of this history being lost in this process, given this case is far less well known than either the Holocaust or the Cambodian genocide.

The existence of memorials and the functions they can perform is a product not only of political support, but also of the resources such memorials require. In less well-known cases of violence, the requirement to universalize messages may be more prevalent. Well-funded memorials can go way beyond the project of universal remembrance of human tragedy. The Holocaust Memorial Museum in Washington has, for example, launched a fund-raising campaign for a "world memory project" through which it hopes to make the 170 million records of the Holocaust and 
Nazi persecution searchable. ${ }^{5}$ The memory project has already made available almost three million documents and it builds on tools from ancestry.com. Through this search tool, a child Holocaust survivor, Sol Finkelstein (2015), comments in a video posted online after being able to view his father's death record: "Now I know where my father is, it's not easier that I know but at least I know". At this stage, it is impossible to imagine comparable resources being provided for a memorial museum that could perform such a function in Indonesia because of the political situation, a lack of resources and poor documentation of the killings in Indonesia, due to again the lack of political will and taboos around Communism.

\section{Conclusions}

The location of Dadang Christanto's evocative bronze sculpture series Heads from the North in the sculpture garden of the NGA is a remarkable example of transcultural memorial to victims of violence that took place in another country. It is particularly remarkable because of the background of the artist, who is the child of a person who disappeared in the 1965 violence. The work conveys both a personal sense of loss and grief, while at the same time asking its audiences to reflect on the larger scale of this violence and Australia's relationship to it.

The memorial is perhaps necessarily framed in terms of more universal messages of the loss and suffering inflicted on those left behind in cases of violent pasts. Yet it does achieve the aim of bringing a relatively forgotten history into memory, and bringing the histories of Australia and Indonesia into dialogue.

\section{Notes}

1. For some critiques of Korean American framing of this issue see Kang (2003) and Yoneyama (2003).

2. For more on the exhibition, see http://sherman-scaf.org.au/exhibition/ dinh-q-le/.

3. See Cribb and Coppel (2009). For some qualifications to this argument concerning anti-Chinese violence in Aceh, see Melvin (2013).

4. The documentary was most likely Carey (1998).

5. Retrieved from http://www.ushmm.org/online/world-memory-project/. 


\section{REFERENCES}

1965 Survivor in search of father's grave gets deported. (2015, October 19). Jakarta Globe. Retrieved from http://countmein.thejakartaglobe.com/ news/1965-purge-survivor-search-fathers-grave-gets-deported-blacklisted.

Barton, G. (2002). Abdurrabman Wabid: Muslim democrat, Indonesian president a view from inside. Honolulu, HI: University of Hawaii Press.

Bloomfield, S. J. (2006). From the museum director. In M. Berenbraum (Ed.), The world must know: The history of the Holocaust as told in the United States Holocaust Memorial Museum (2nd ed., pp. viii-ix). Washington: United States Holocaust Memorial Museum.

Broinowski, A. (1992). The yellow lady: Australian impressions of Asia. Melbourne: Oxford University Press.

Carey, M. (1998). Indonesia's killing fields. Dateline Television Series, 25 August.

Cribb, R. (1990). The Indonesian killings of 1965-1966: Studies from Java and Bali. Clayton, VIC: Centre of Southeast Asian Studies, Monash University.

Cribb, R., \& Coppel, C. A. (2009). A genocide that never was: Explaining the myth of anti-Chinese massacres in Indonesia, 1965-66. Journal of Genocide Research, 11(4), 447-465.

Drowning his sorrows, victim of the disappeared. (2004, October 1). Sydney Morning Herald, p. 2.

Eastburn, M. (2008). Dadang Christanto, washing the wound. TAASA Review, $17(4), 24$.

Erll, A. (2011). Travelling memory. Parallax: A Journal of Metadiscursive Theory and Cultural Practices, 17(4), 4-18.

Finkelstein, S. (2015). Interview featured on the promotional video, The power of truth is in your history. World Memory Project. Retrieved from http://www. ushmm.org/online/world-memory-project/.

Hearman, V. (2013). Dismantling the "fortress": East Java and the transition to Subarto's New Order regime (1965-68) (Doctoral dissertation, The University of Melbourne, Melbourne, Australia).

Hill, D. (2009). Knowing Indonesia from afar: Indonesian exiles and Australian academics. Review of Indonesian and Malaysian Affairs, 43(1), 147-164.

Hyland, T. (2008, January 20). In praise of a dictator. The Age. Retrieved from http://www.theage.com.au/news/opinion/in-praise-of-a-dictator/2008/ $01 / 19 / 1200620275283 . h t m l$.

Ingham, S. (2003). Witnesses from Indonesia. TAASA Review, 2(4), 22-23.

Islam, S. M. (1999). Writing the postcolonial event: Salman Rushdie's August 15th, 1947. Textual Practice, 13(1), 119-135.

Jenkins, D., \& Kammen, D. (2012). The army para commando regiment and the reign of terror in Central Java and Bali. In D. Kammen \& K. McGregor (Eds.), The contours of mass violence in Indonesia, 1965-1968 (pp. 75-103). Singapore: NUS Press. 
Kang, H. Y. (2003). Conjuring comfort women: Mediated affiliations and disciplined subjects in Korean American transnationality. Journal of Asian American Studies, 6(1), 25-55.

Kronenberg, Y., \& Herbert, R. (2006). Conversations with Australian artists, dvd (Dadang Christanto) (Vol. 2). Sydney: Public Programs Department, Art Gallery of NSW.

Mackie, J. A. C. (1974). Konfrontasi: The Indonesia-Malaysia dispute, 19631966. Kuala Lumpur and New York: Oxford University Press.

Maxwell, R. (2004). From the north: Dadang Christanto. Artonview, 58, 30-31.

McCarthy, M. M. (2014). US comfort women memorials: Vehicles for understanding and change. Asia Pacific Bulletin, 275. Retrieved from http://www. eastwestcenter.org/sites/default/files/private/apb275.pdf.

McGregor, K. E. (2004). Museums and the transformation from colonial to post-colonial institutions in Indonesia. In F. Kerlogue (Ed.), Performing objects: Museums, material culture and performance in Southeast Asia (contributions on critical museology and material culture series) (pp. 15-29). London: Horniman Museum.

McGregor, K. E. (2012). Mass graves, memory and meaning: Disputes over the 1965-1966 killings. In D. Kammen \& K. McGregor (Eds.), The contours of mass violence in Indonesia, 1965-1968 (pp. 234-262). Singapore: NUS Press.

Melvin, J. (2013). Why not genocide: Anti-Chinese violence in Aceh, 19651966. Journal of Current Southeast Asian Affairs, 32(3), 63-91.

Najjarine, K., \& Cottle, D. (2003). The Department of External Affairs, the ABC and reporting of the Indonesian crisis 1965-1969. Australian Journal of Politics and History, 49(1), 48-60.

Narudin, N. (2015, June 8). Kompleks makam korban peristiwa 1965 dibangun (Tomb complex is built for the victims of the 1965 events). Kompas. Retrieved from http://regional.kompas.com/read/2015/06/08/1227599/ Kompleks.Makam.Korban.Peristiwa.1965.Dibangun.

National Art Gallery Committee of Inquiry. (1966). Report of National Art Gallery Committee of inquiry. Canberra: n.p., 14 March.

Ng, E. W. (2014). Gene Sherman: Rebel with a cause. Art and Asia Pacific, 89, 52-53.

Peterson, A. R. (2013). The locations of memory: Migration and transnational cultural memory as challenges for art history. Crossings: Journal of Migration and Culture, 4(2), 121-137.

Purwadi, B. (2003). Mematabkan pewarisan ingatan: Wacana anti-Komunis dan politik rekonsilliasi pasca Soeharto [Breaking the inheritance of memories: Anti-Communist discourse and post-Soeharto politics of reconciliation]. Jakarta: ELSAM.

Schlund-Vials, C. J. (2012). Cambodian American memory work: Justice and the Cambodian syndrome. Positions, 20(3), 805-830.

Sherman, G. (2009). Sherman Contemporary Art Foundation: From vision to venture. In N. Jose (Ed.), Contemporary art and philanthropy: Private foundations: Asia-Pacific focus (pp. 60-69). Sydney: Power Publications. 
Tanter, R. (2002, July-September). Witness denied. Inside Indonesia, 71. Retrieved from http://www.insideindonesia.org/witness-denied.

Tapsell, R., \& Eidenfalk, J. (2013). Australian reporting from East Timor 1975-1999: Journalists as agents of change. Australian Journal of Politics \& History, 59(4), 576-592.

Turner, C. (2007a). Dadang Christanto: The head as the site of memory. In C. Turner \& D. Williams (Eds.), Thresholds of tolerance (pp. 45-50). Canberra, ACT: Australian National University.

Turner, C. (2007b). Wounds in our heart: Identity and social justice in the art of Dadang Christanto. In K. Robinson \& R. Werbner (Eds.), Asian and Pacific cosmopolitans, self and subject in motion (pp. 77-99). Basingstoke, UK: Palgrave Macmillan.

Yoneyama, L. (2003). Travelling memories, contagious justice: Americanization of Japanese war crimes at the end of the post-Cold War. Journal of Asian American Studies, 6(1), 57-93.

Open Access This chapter is licensed under the terms of the Creative Commons Attribution 4.0 International License (http://creativecommons.org/licenses/ by $/ 4.0 /)$, which permits use, sharing, adaptation, distribution and reproduction in any medium or format, as long as you give appropriate credit to the original author(s) and the source, provide a link to the Creative Commons license and indicate if changes were made.

The images or other third party material in this chapter are included in the chapter's Creative Commons license, unless indicated otherwise in a credit line to the material. If material is not included in the chapter's Creative Commons license and your intended use is not permitted by statutory regulation or exceeds the permitted use, you will need to obtain permission directly from the copyright holder.

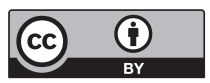

